\title{
Does the use of high dose atorvastatin in combination with dual antiplatelet therapy modify residual platelet activity in patients with acute coronary syndrome?
}

\author{
DSaša Pavasović*, \\ DDubravka Šipuš, \\ DJure Samardžić, \\ (DHrvoje Jurin, \\ DMarijan Pašalić, \\ DBoško Skorić, \\ Daja Čikeš, \\ DDanijel Lovrić, \\ DJana Ljubas Maček, \\ DIvo Planinc, \\ DDavor Miličić
}

University of Zagreb School of Medicine, University Hospital Centre Zagreb, Zagreb, Croatia

\begin{abstract}
KEYWORDS: platelet reactivity, acute coronary syndrome, P2Y12 inhibitors, statins. CITATION: Cardiol Croat. 2019;14(9-10):213. | https://doi.org/10.15836/ccar2019.213

*ADDRESS FOR CORRESPONDENCE: Saša Pavasović, Klinički bolnički centar Zagreb, Kišpatićeva 12, HR-10000 Zagreb, Croatia. / Phone: +385-1-2367-466 / E-mail: pavasovic.sasa@gmail.com

ORCID: Saša Pavasović, https://orcid.org/0000-0002-3705-0226 • Dubravka Šipuš, https://doi.org/0000-0002-5631-0353 Jure Samardžić, https://orcid.org/0000-0002-9346-6402•Hrvoje Jurin, https://orcid.org/0000-0002-2599-553X Marijan Pašalić, https://orcid.org/0000-0002-3197-2190 • Boško Skorić, https://orcid.org/0000-0001-5979-2346 Maja Čikeš, https://orcid.org/0000-0002-4772-5549 • Danijel Lovrić, https://orcid.org/0000-0002-5052-6559

Jana Ljubas Maček, https://orcid.org/0000-0001-7171-2206 • Ivo Planinc, https://orcid.org/0000-0003-0561-6704 Davor Miličić, https://orcid.org/0000-0001-9101-1570
\end{abstract}

IIIIIIIIIIIIIIIIIIIIIIIIIIIIIIIIIIIIIIIIIIIIIIIIIIIIIIIIIIIIIIIIIIIIIIIIIIIIIIIIIIIIIIIIIIIIIIIIIIIIIIIIIIIIIIIII

Introduction: Dual antiplatelet therapy (DAPT) represents one of the pillars in the treatment of acute coronary syndromes (ACS) ${ }^{1}$. In the past the most commonly used combination of antiplatelet drugs has been acetylsalicylic acid (ASA) and clopidogrel. Clopidogrel had a high incidence rate of high residual platelet reactivity and has, in recent years, been replaced with ticagrelor, a more potent platelet inhibitor with a more uniformed response across the patient population. The effect of high dose atorvastatin on platelet reactivity mediated by ASA and clopidogrel is well researched, however no studies have been published analyzing this effect when clopidogrel is substituted with ticagrelor. Purpose: To investigate if high dose atorvastatin modifies PF mediated by DAPT in patient with ACS as measured by platelet function tests (PFTs).

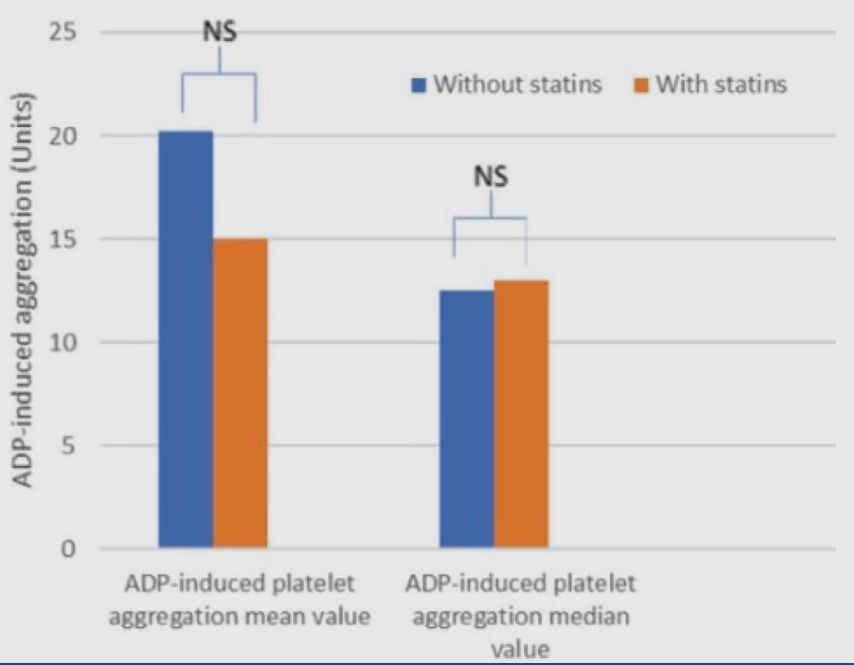

FIGURE 1. Platelet reactivity with and without high dose atorvastatin. NS = non-significant

Patients and Methods: We analyzed clinical characteristics and PF in patients presenting with ACS at the Department of Cardiovascular Diseases at the University Hospital Centre Zagreb from December 2015 to February 2018. Primary endpoint was PF after treatment with DAPT and/or high dose atorvastatin. We analyzed PF using the Multiplate platelet function analyzer. PFTs were performed 18-24 hours after therapy initiation. None of the patients were taking statins before the index event.

Results: There were 35 patients with a mean (SD) age of 61.6 (12.2) years in the atorvastatin group and 29 patients with a mean (SD) of 62.6 (9.6) years in the no-atorvastatin group. Both groups were identical in all the baseline parameters except history of hyperlipidemia (34.5\% vs $65.7 \%, \mathrm{P}=0.023)$. There were no significant differences between the two groups in PF analyzed with PFTs (Figure 1). The difference in residual platelet reactivity remained non-significant even after adjusting for sex, age and hyperlipidemia as the only co-variate that was significantly different between the group $(\mathrm{P}=0.432)$.

\section{RECEIVED:}

August 28, 2019

ACCEPTED:

September 16, 2019

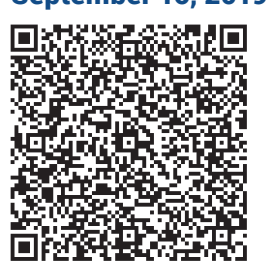

Conclusion: In this pilot study on a limited sample we found no difference in residual PF in patients on DAPT weather they are on treatment with high dose atorvastatin or not. These results show that the pleiotropic effects of atorvastatin on platelet reactivity are not significant in patients taking DAPT with ticagrelor and ASA.

Acknowledgement: This pilot study was funded by Croatian Science Foundation.

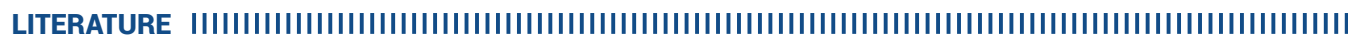

1. Valgimigli M, Bueno H, Byrne RA, Collet JP, Costa F, Jeppsson A, et al; ESC Scientific Document Group; ESC Committee for Practice Guidelines (CPG): ESC National Cardiac Societies. 2017 ESC focused update on dual antiplatelet therapy in coronary artery disease developed in collaboration with EACTS: The Task Force for dual antiplatelet therapy in coronary artery disease of the European Society of Cardiology (ESC) and of the European Association for Cardio-Thoracic Surgery (EACTS). Eur Heart J. 2018 Jan 14;39(3):213-260. https://doi.org/10.1093/eurheartj/ehx419 